Coolabah, No.23, 2018, ISSN 1988-5946, Observatori: Centre d'Estudis Australians / Australian Studies Centre, Universitat de Barcelona

\title{
Coolabah 23: The Short Poem Issue
}

With poems by Adam Aitken, Amanda Anastasi, Grant Caldwell, Aidan

Coleman, Dan Disney, Joe Dolce, Laurie Duggan, Marisa Fazio, Barry Gillard, Jeff Guess, Matt Hetherington, Andy Jackson, Ross Jackson, Leanne Jaeger, John Jenkins, Ray Liversidge, Justin Lowe, Mark Mahemoff, Michaela Mark, Alex McKeown, Julian McLucas, Jan Napier, Nathanael O'Reilly, Geoff Page, Gregory Piko, Jan Price, Chris Ringrose, Rob Scott, Lel Sebastian, and Claire Rosslyn Wilson, who also provides the closing essay.

Edited by Peter Bakowski 
Coolabah, No.23, 2018, ISSN 1988-5946, Observatori: Centre d'Estudis Australians / Australian Studies Centre, Universitat de Barcelona

Foreword to the Coolabah short-poem issue

Peter Bakowski

\begin{abstract}
Copyright@2018 Peter Bakowski. This text may be archived and redistributed both in electronic form and in hard copy, provided that the author and journal are properly cited and no fee is charged, in accordance with our Creative Commons Licence.
\end{abstract}

As a practitioner of the short poem for 34 years, I have been and remain on the lookout for other practitioners. By putting on an editorial hat and placing a callout for 1 to 5-line poems via the Australian Poetry e-newsletter, I've hearteningly found numerous practitioners. It's been a rewarding experience for me and now it may be for you, dear reader.

"Make your next poem different from your last" is a quote attributed to Robert Frost and it is quality, difference and variety I've sought to honour in my selection. Poets continue to see the world from their own perspective, through their own history, environment and sifting process while keeping in mind what's universal. What has caught their attention, engaged their senses, thinking and powers of observation they've found necessary to reveal via poems. The poems in this selection look inward and outward, span the world and are domestic, they record the "voices" of the child and the elder.

The short poem has its appeal - it's lean, exacting, pithy - wit, wisdom, wordplay and wonder whittled into a dart aimed to hit the bullseye which is you, dear reader. I don't want to kill the short poem by defining it. Via the formatting of the poems I've given the poems breathing space - as composer Erik Satie knew, the spaces between the notes are as important as the notes. I'll leave you the space to wander and wonder amongst the poems. 
Coolabah, No.23, 2018, ISSN 1988-5946, Observatori: Centre d'Estudis Australians / Australian Studies Centre, Universitat de Barcelona

\section{MARK MAHEMOFF}

\section{Babushka}

Before my grandmother died at 92 she asked if the internet was closed on a Sunday.

She's at home in her own skin. I'm a squatter in mine. 
Coolabah, No.23, 2018, ISSN 1988-5946, Observatori: Centre d'Estudis Australians / Australian Studies Centre, Universitat de Barcelona

\section{MARK MAHEMOFF}

The taller my son grows the further away he wants me to stand.

My mother's death made space for me to make sense of her life. 
Coolabah, No.23, 2018, ISSN 1988-5946, Observatori: Centre d'Estudis Australians / Australian Studies Centre, Universitat de Barcelona

\section{JAN PRICE}

He shackles the hands of his deaf wife to sign insults at her.

Headstones are for the living 
Coolabah, No.23, 2018, ISSN 1988-5946, Observatori: Centre d'Estudis Australians / Australian Studies Centre, Universitat de Barcelona

\section{JAN PRICE}

In Mass

she tells her son to sit still and give time to God -

it's ten past God - he says.

Before sin there was curiosity. 
Coolabah, No.23, 2018, ISSN 1988-5946, Observatori: Centre d'Estudis Australians / Australian Studies Centre, Universitat de Barcelona

\section{JAN PRICE}

"Pass the salt" is conversation caviar between long married couples.

\footnotetext{
A little girl kneels down calls out $\mathrm{He}$ ello into a flower-grate at the foot of a grave.
} 
Coolabah, No.23, 2018, ISSN 1988-5946, Observatori: Centre d'Estudis Australians / Australian Studies Centre, Universitat de Barcelona

\section{MICHAELA MARK}

A 'real' job feels like acting.

My mother complains of the ill effects of salt in the diet as she salts her steak and mash. 
Coolabah, No.23, 2018, ISSN 1988-5946, Observatori: Centre d'Estudis Australians / Australian Studies Centre, Universitat de Barcelona

\section{BARRY D. GILLARD}

\section{Three ceramic mallards}

Small steps wander along the polished floorboards of the hallway in the house, where the three ceramic

mallards flew their flight nailed to the wall and their single eyes, ablaze, forever craved the door.

\section{Emma Morano}

Emma Morano, born in 1900, the year Puccini penned his shabby shocker Tosca, as Kerman called it, is gone now and no longer the oldest person in the world. She was one hundred and seventeen her credo had been three eggs a day, two raw, brandy infused with seven leaves of sage, to breath fresh air and stay away from men. 
Coolabah, No.23, 2018, ISSN 1988-5946, Observatori: Centre d'Estudis Australians / Australian Studies Centre, Universitat de Barcelona

\section{JEFF GUESS}

Moss on a train station wall waits for the soft errands of the rain.

History has failed us - but there's more to come. 
Coolabah, No.23, 2018, ISSN 1988-5946, Observatori: Centre d'Estudis Australians / Australian Studies Centre, Universitat de Barcelona

\section{JEFF GUESS}

Sad words, 'What party?'

I can't attribute this shiver to the cold. 
Coolabah, No.23, 2018, ISSN 1988-5946, Observatori: Centre d'Estudis Australians / Australian Studies Centre, Universitat de Barcelona

\section{ADAM AITKEN}

\section{Jalan Tun Razak, Kuala Lumpur}

The gardener stacks the fertiliser bags in front of the US embassy.

\section{Klang, Selangor}

A plague of swamp mosquitoes

leaves the unemployed scratching their heels. 
Coolabah, No.23, 2018, ISSN 1988-5946, Observatori: Centre d'Estudis Australians / Australian Studies Centre, Universitat de Barcelona

\section{DAN DISNEY}

\section{Two sijo(stlings)}

' $\&$ what if we're part flower, part crowd, part sewer, part cloud' she said eyeing a mosquito at the bathroom window's wire, long dead

then one day PUFF (gone)

think of it, with your body
'I know,' she says '...you also

>> hard against mine?
$\&$ the boutiques of Shinsegae

the SALE! bling windowless, foregrounding piled shine of things in muddling vistas

promising I AM $\quad$ > s shopping twitterers echoing

frisson \& (outside, cicadas I'M-ING their $t z z z$ in nude sun)


Coolabah, No.23, 2018, ISSN 1988-5946, Observatori: Centre d'Estudis Australians / Australian Studies Centre, Universitat de Barcelona

\section{NATHANAEL O’REILLY}

\section{Cow parking}

In the shadow of the giant fiberglass cow at Amarillo's Big Texan Steakhouse there's an udderly perfect place to park.

\section{Misnomer}

In the suburbs of Vienna a station named Simmering fails to live up to its name. 
Coolabah, No.23, 2018, ISSN 1988-5946, Observatori: Centre d'Estudis Australians / Australian Studies Centre, Universitat de Barcelona

\section{LAURIE DUGGAN}

\section{The Body Politic}

Get off the fence step up to the plate $\&$ kick the hot potato into the long grass.

\section{Transcription Haiku}

Japanese compilers suspect musical pun On Green Dolphy Street 
Coolabah, No.23, 2018, ISSN 1988-5946, Observatori: Centre d'Estudis Australians / Australian Studies Centre, Universitat de Barcelona

\section{JOHN JENKINS}

Don't open!

Locked suitcase on a beach.

Inside, a tidal wave.

Overheard on bus

"It was like ...

grasping at fogwebs." 
Coolabah, No.23, 2018, ISSN 1988-5946, Observatori: Centre d'Estudis Australians / Australian Studies Centre, Universitat de Barcelona

\section{CLAIRE ROSSLYN WILSON}

Pressed by the sun's angle

shadows don't show

our fight with the wind.

Here: I've not yet learnt how to waste my time to my taste. 
Coolabah, No.23, 2018, ISSN 1988-5946, Observatori: Centre d'Estudis Australians / Australian Studies Centre, Universitat de Barcelona

\section{CLAIRE ROSSLYN WILSON}

Rain clouds clearing later the weatherman promised, but for now unrest.

New hairdresser: she'll get it wrong 'til I shrug off past cuts. 
Coolabah, No.23, 2018, ISSN 1988-5946, Observatori: Centre d'Estudis Australians / Australian Studies Centre, Universitat de Barcelona

\section{MARISA FAZIO}

On a Naples street a barefoot boy selling socks

leaning in to read the sundial our shadows almost touch. 
Coolabah, No.23, 2018, ISSN 1988-5946, Observatori: Centre d'Estudis Australians / Australian Studies Centre, Universitat de Barcelona

\section{MARISA FAZIO}

Deleting all photos of us I keep the landscapes.

bedside vigil - another rose falls from the vase 
Coolabah, No.23, 2018, ISSN 1988-5946, Observatori: Centre d'Estudis Australians / Australian Studies Centre, Universitat de Barcelona

\section{AMANDA ANASTASI}

You need not have your eyes open to know that the sun is out. 
Coolabah, No.23, 2018, ISSN 1988-5946, Observatori: Centre d'Estudis Australians / Australian Studies Centre, Universitat de Barcelona

\section{GREGORY PIKO}

jellyfish handbags

bobbing at a summer sale 
Coolabah, No.23, 2018, ISSN 1988-5946, Observatori: Centre d'Estudis Australians / Australian Studies Centre, Universitat de Barcelona

JOE DOLCE

\section{Ears Have Walls}

What goes down must come up.

The cage in a gilded bird.

Worked his bone to the finger.

A stomach in his butterflies.

The ears have walls.

\section{Poetry Is Like Looking}

Poetry is like looking

for a haystack in a needle. 
Coolabah, No.23, 2018, ISSN 1988-5946, Observatori: Centre d'Estudis Australians / Australian Studies Centre, Universitat de Barcelona

\section{JOE DOLCE}

\section{Shakezheimers}

To be or

\section{Voltaire Left}

I may not agree with what you say,

But I will attack, to your death,

for my Right not to hear it. 
Coolabah, No.23, 2018, ISSN 1988-5946, Observatori: Centre d'Estudis Australians / Australian Studies Centre, Universitat de Barcelona

\section{GEOFF PAGE}

Patience in the coffee queue. Sunday morning's sermon.

The poodle or the matron? Who is leading whom? 
Coolabah, No.23, 2018, ISSN 1988-5946, Observatori: Centre d'Estudis Australians / Australian Studies Centre, Universitat de Barcelona

\section{JUSTIN LOWE}

\section{Stocktake}

that dark mood when the shutters come down. abilities in one column, ambitions in the other, and a line crossed hard through achievements. this isn't prize day, mate, it's an inventory. Let's see what's left on the shelves.

\section{Dark Star}

shuffles to a stool.

midges of feedback from a dying guitar.

raises the light like Christ would the dead.

woman is an enigma, he groans into his mic

as the phone cameras carve out each year on his face. 
Coolabah, No.23, 2018, ISSN 1988-5946, Observatori: Centre d'Estudis Australians / Australian Studies Centre, Universitat de Barcelona

\section{ROSS JACKSON}

traffic lights

outside the maternity hospital

still on amber.

during the Ice Age so many reasons not to have sex, yet here we are. 
Coolabah, No.23, 2018, ISSN 1988-5946, Observatori: Centre d'Estudis Australians / Australian Studies Centre, Universitat de Barcelona

JULIAN MCLUCAS

Phonetic Onomatopoetic Palindrome poem

pop

\section{Reciprocity poem}

fly from sight sigh from flight 
Coolabah, No.23, 2018, ISSN 1988-5946, Observatori: Centre d'Estudis Australians / Australian Studies Centre, Universitat de Barcelona

\section{JULIAN MCLUCAS}

-realism-

sur

realism

sous

\section{Autumnal hymn, outside}

Autumnal hymn, outside a leaf lands, exotic as a spacecraft, yet we look for bigger things 
Coolabah, No.23, 2018, ISSN 1988-5946, Observatori: Centre d'Estudis Australians / Australian Studies Centre, Universitat de Barcelona

\section{RAY LIVERSIDGE}

\section{Rothko}

the more we look the more we see

the more we see the more we look 
Coolabah, No.23, 2018, ISSN 1988-5946, Observatori: Centre d'Estudis Australians / Australian Studies Centre, Universitat de Barcelona

\section{ALEX MCKEOWN}

The reddening face of the child who watches

other children play as a grown-up asks

what are your friends' names? 
Coolabah, No.23, 2018, ISSN 1988-5946, Observatori: Centre d'Estudis Australians / Australian Studies Centre, Universitat de Barcelona

\section{ANDY JACKSON}

the sound of dawn birdsong

for the insects

is not an epiphany 
Coolabah, No.23, 2018, ISSN 1988-5946, Observatori: Centre d'Estudis Australians / Australian Studies Centre, Universitat de Barcelona

\section{CHRIS RINGROSE}

\section{Sisters}

Still good, from time to time to share a double bed, whispering secrets, till one of us is asleep and doesn't answer. 
Coolabah, No.23, 2018, ISSN 1988-5946, Observatori: Centre d'Estudis Australians / Australian Studies Centre, Universitat de Barcelona

\section{CHRIS RINGROSE}

when I fell silent

they all listened

you can only repeat

the past 
Coolabah, No.23, 2018, ISSN 1988-5946, Observatori: Centre d'Estudis Australians / Australian Studies Centre, Universitat de Barcelona

\section{MATT HETHERINGTON}

An endless line of hands -

all the beggars

I never gave to.

how can he hear, now his mask is stuck? 
Coolabah, No.23, 2018, ISSN 1988-5946, Observatori: Centre d'Estudis Australians / Australian Studies Centre, Universitat de Barcelona

\section{LEL SEBASTIAN}

early evening walk in summer

noisy grass until I get close

\section{Paperbark Forest}

Sunlight has pinned notices

to only three of the trees. 
Coolabah, No.23, 2018, ISSN 1988-5946, Observatori: Centre d'Estudis Australians / Australian Studies Centre, Universitat de Barcelona

\section{LEANNE JAEGER}

You touch me without touching me

The treasure is in the trying 
Coolabah, No.23, 2018, ISSN 1988-5946, Observatori: Centre d'Estudis Australians / Australian Studies Centre, Universitat de Barcelona

\section{ROB SCOTT}

waking from a dream I lose my dad again

peace rally children fight over a balloon 
Coolabah, No.23, 2018, ISSN 1988-5946, Observatori: Centre d'Estudis Australians / Australian Studies Centre, Universitat de Barcelona

\section{JAN NAPIER}

drying on the line dragonfly wings 
Coolabah, No.23, 2018, ISSN 1988-5946, Observatori: Centre d'Estudis Australians / Australian Studies Centre, Universitat de Barcelona

\section{GRANT CALDWELL}

in hundreds of years

you have not learned about windows

bee 
Coolabah, No.23, 2018, ISSN 1988-5946, Observatori: Centre d'Estudis Australians / Australian Studies Centre, Universitat de Barcelona

\section{GRANT CALDWELL}

blind man running loudly up the stairs he knows are there

arguing about war no-one wins 
Coolabah, No.23, 2018, ISSN 1988-5946, Observatori: Centre d'Estudis Australians / Australian Studies Centre, Universitat de Barcelona

\section{AIDAN COLEMAN}

Cats sprawl like accordions. Velcro soles.

\section{Shed light}

Insects hang like burnt-out planets. 
Coolabah, No.23, 2018, ISSN 1988-5946, Observatori: Centre d'Estudis Australians / Australian Studies Centre, Universitat de Barcelona

\author{
Foreword to Claire Rosslyn Wilson's essay "Walking to Montjuïc: Cycles of \\ Belonging"
}

Peter Bakowski

\begin{abstract}
Copyright $@ 2018$ Peter Bakowski. This text may be archived and redistributed both in electronic form and in hard copy, provided that the author and journal are properly cited and no fee is charged, in accordance with our Creative Commons Licence.
\end{abstract}

This essay conveys the first-hand experience of the overseas traveller in a foreign city. There is a certain wisdom in trying to understand, infiltrate, perhaps eventually ease into a single city which is not your city of birth, not your hometown, rather than try to understand a whole country and its place in Europe and the world.

It is the attention to detail that gives the poet a key, a beginning, a seed - to start with the flowerpot on the balcony, then take in the street, widen the view to the neighbourhood and convey whether it is representative or unique, rushed through on the way to elsewhere or a cherished destination.

Cemeteries remain an attraction for poets. The state of the graves, the headstones, their grandness or decline, the very ordinary or exotic names inscribed, the broken wing of a stone angel, all have the poet imagining the dead, the concentric circles of the living, the emotions spent, unnameable or not yet reconciled.

Claire Rosslyn Wilson reminds us of the importance of cafés, where if we understand the café's "codes", the clientele, the staff, the neighbourhood, how it is all ballet and theatre, we may perhaps succeed in making that transition from stranger, almost intruder, to greeted, even smiled at, regular. A personal triumph, internally applauded.

Claire Rosslyn Wilson also reminds us that travel is work. A wrong turn may be taken. Suddenly there's a hot dusty wind or pelting rain, we forgot to pack a picnic lunch, a passerby steps on our toe and we are reduced in our own eyes to the unsophisticated traveller, perhaps open game for watchful eyes.

The essay may remind the reader why in this century there are reputed to be one million human beings in aircraft at any one time. Some are seeking a bargain, some are after some pampering, some are working on their bucket list or their Spanish. Some wanted to simply get away, but nothing is simple dear reader, dear traveller.

Venture forth along the pathways of this essay with Claire.

Peter Bakowski, Richmond, Melbourne, 11 December 2017 


\title{
Coolabah, No.23, 2018, ISSN 1988-5946, Observatori: Centre d'Estudis Australians / Australian Studies Centre, Universitat de Barcelona
}

Walking to Montjuïc: Cycles of belonging

\author{
Claire Rosslyn Wilson \\ PhD candidate, University of Canberra
}

\begin{abstract}
Copyright@2018 Claire Rosslyn Wilson. This text may be archived and redistributed both in electronic form and in hard copy, provided that the author and journal are properly cited and no fee is charged, in accordance with our Creative Commons Licence.
\end{abstract}

\begin{abstract}
A personal essay by poet Claire Rosslyn Wilson that reflects on her recent practiceled creative writing research in the unfamiliar context of Barcelona while she was a visiting researcher at the Australian Studies Centre at the University of Barcelona. The essay explores the process of adapting to a new place and the ways of learning to live between places.
\end{abstract}

Keywords: creative writing, cultural adaptation, translocal

\section{Balconies}

'Place is the product of a relationship - part subjective projection, part internalisation of an external reality' (Curtis 2001: 55).

The sun is weak in the morning, coming in at an angle that barely reaches the end of the lounge room, while it glares brightly on the green awnings on the opposite building. I stare at them as I have my breakfast. I'm not good at routines. I resist them even more when I'm just starting to work out how to belong in a city I don't know intimately. If I wanted a routine why not just stay in the same city that's familiar, rather than cross the globe to live in Barcelona?

When I was younger I thought of travel as a way to collect stories to write about, exotic tales and exciting mishaps that could litter my poetry. But I've found living in a number of cities has a different way of getting into my work. It's not the stories so much as the feeling of slight discomfort, the small daily challenges that inspire my creative work and keep me pushing further and further away from the familiar.

The awnings on the flats opposite flutter, creating a ripple down the long building. If I stick my head out the window I can see down the busy street, a slight curve eventually cutting off my sightlines in both directions. I have to look carefully to see the lives within, separated from me by ten meters and a long drop. We mostly hide inside our boxes, curtains drawn and just 


\section{Coolabah, No.23, 2018, ISSN 1988-5946, Observatori: Centre d'Estudis Australians / Australian Studies Centre, Universitat de Barcelona}

thick enough to shield our lives. People step out onto their balconies - hang the washing, water the plants, sweep - before scuttling inside again. There is one house that lights up at night, where, as I peer in, the family is sitting chatting at the dining room table, before the kids disappear to bed and a parent finally relaxes on the couch. There are a few smokers who brave the waves of noise from the cars below as they perch on their chairs for their last evening cigarette. We watch each other out of the corner of our eyes, holding on to our own spaces.

There are two cats opposite that I worry about as they weave around the obstacles on their balcony, popping in and out of the window with a nonchalance that unnerves me. I'm not sure how their owners have taught them to avoid the thin rail dividing the house from the long drop to the street below. Maybe Barcelona's cats have an instinct, bred into them by living in the stacked flats of this city, that keeps them away from the edges. I watch the two of them baking in the sun while my mind replays our clumsy family cat years ago falling out of the tree to land harmlessly into the rose bush half a meter below. Cats don't always land on their feet.

Lately the balconies have become political declarations, with flags declaring pro, anti or something in between. Some nights after dinner at 10pm I've stood outside banging a pot with a wooden spoon and watched shadowy neighbours stand in the dark to declare their frustration. People walking dogs in the street below have stared up at the noise. There is a neighbour on one corner who uses the protest to practice drumming beats, banning out music long after everyone has retired. The clamour rose over the whole city for weeks.

I glance at my balcony, without a cat as yet but with some herbs in various stages on a scale of growth to decay. In other cities I've been used to rosemary bushes that push other plants out of the way or mint that grows thickly to half a meter. But I haven't yet worked out the light and shadow in this narrow outside space and life can turn quickly in a small pot. I watch from the inside, breakfast finished, considering the movement of the wind and the leaves in the shade.

I keep the noise sealed behind double-glazed glass.

\section{Overlapping views}

'Translocal geographies [can be] a simultaneous situatedness across different locales which provide ways of understanding the overlapping place-time(s) in migrants' everyday lives' (Brickell and Datta 2011: 4).

Plane trees are everywhere.

I first really noticed them one spring in Melbourne when I was working in a restaurant that faced onto a picturesque street near the beach. All the streets in the neighbourhood were lined with the vibrant green leaves, their uniformity creating beautiful tunnels as their seed pods broke open and rained pollen onto the streets. That was the first year I got hay fever, crying plane tree dust. In Barcelona I still sneeze, even though their leaves are sparse and slightly more browned, coated with a thin layer of dust, their trunks thinner as they're forced into a smaller square of dirt between the paving stones. 


\section{Coolabah, No.23, 2018, ISSN 1988-5946, Observatori: Centre d'Estudis Australians / Australian Studies Centre, Universitat de Barcelona}

I dodge past their roots as I make my way down the busy street to my regular corner coffee shop. It's a franchise, one of many that are emerging in shop fronts everywhere, selling bread and coffee with minimal smiles. I don't come here for the waiters' charisma or for the TV blaring in the background, I come for its big windows and the open space of the square it faces. When I look up from my table I can see the sky, not just peaking between buildings, but a vast expanse of it. I can see the weather drift, patches of cloud with tracts of sky. I can see the sun filter through the plane tree leaves and make patterns on the pavement.

Coffee shops give me patterns I repeat in different cities with only small variations.

This square I watch from behind the large coffee shop windows has its own ecology of daily life - the newspaper booth with changing faces of strangers staring up at me from the latest gossip magazines, the small pile of uncooked rice that materialises and disappears again just outside the metro exit, the guy carting around his guitar and taking his early morning coffee with conversation, the waiters making bawdy jokes with their retired regulars, the flower lady bringing her plants by the trolley load from a side street behind the café. I notice it all in parts, catching sections of the routines that keep this corner of the city busy.

\section{Rough surfaces}

\footnotetext{
"'Knowing" the city invites, and invokes, a need to know the self... What we call objective historical knowledge cannot be separated from a fluid network of cross-linking, feedbacking, constantly shifting and reciprocal relations between outer and inner worlds, between the city and the self' (Rendall 2001, 108).
}

I've been learning the city as I circled round its islands. I've built my familiarity of this place by pulling together its individual spaces with a thin thread through time and place. These pools of knowledge gather around my Catalan classes, the university, apartments of friends, bars, restaurants, galleries, a circus or two. The spaces between not yet mapped when I take the metro. I once crossed the border into L'Hospitalet de Llobregat, the invisible line between one city and the next fell somewhere between busy roads and tall buildings. Barcelona is a walkable city, compact so that you are never so far away from where you need to be - I discover the grids of the city by walking the pavements.

But some days the roar of the cars, voices, shouts and horns overtakes my spiralling walks. On these days I don't look up, just keep my eyes fixed on the pavement a meter and a half in front of me and hurry home. I dance between the plane tree roots and pavement, walking a wavering line to avoid the crowds and traffic.

It's a city of walkers with not enough pavements for us all.

In the months here I've walked my spirals, slowly increasing the known, but often returning to these places where I don't have to think, just exist in the familiar. I hang onto the things that fit like old pyjamas - the squawks of parrots, their colourful dashes between leaves, open space between tall buildings, grass, rambles unhindered by cross-roads. I use these patterns, familiar from other places, to wash over me while my mind resets. 


\section{Coolabah, No.23, 2018, ISSN 1988-5946, Observatori: Centre d'Estudis Australians / Australian Studies Centre, Universitat de Barcelona}

I displace myself for the irritation of the unknown, but I can only be outside of my skin for so long at a time. I write out my discomforts, trying to track the known against the unknown, but the dividing line between the two is constantly changing. My habits and comforts slip and merge so that when I look back I don't recognise my footprints.

My short poems, framed in the streets of Barcelona, pin fragments to my changing wall of cultural understanding, creating a post-it collage that oscillates between acceptance and confusion. The fragments overlap the more I write, each piece reframing and adjusting what I think I know about this place.

I once tried to pick up a pile of dirt and bring it home with me from the nearby Rambla de Brasil, a piece of the land in my apartment as a reminder of where I was. But the dirt was filled with dog piss, hard packed from rain and footsteps, compressed into a surface as solid as cement.

\section{Cemetery flowers}

'The spaces of the city are as much real as imagined...the spatialities of the body are bound up in the production of urban spaces, and that there are very strong emotional investments in the spaces of the city' (Pile 2001: 268).

The skin on the heels of my feet is starting to peel off layer by layer as I walk to Montjuïc Cemetery.

The streets towards the cemetery are more sparsely populated and it feels like I'm heading into a dead end. In a way I guess I am as the cemetery is perched on the edge of a hill with the port at its feet and behind that, the open Mediterranean. I'm tired before I've even made it to the cemetery, the sun relentless in late morning and I realise I haven't packed a lunch.

Tucked away on the slopes of a hill, Montjuïc Cemetery was established to cater for the growing city and now houses over one hundred and fifty thousand people. The majority of the graves are built into walls that stretch long and high. As I stand at the base of the hill and look up I see tier upon tier of these walls, the road curves in s-bends up the hill. Many of Montjuïc's residents have views out to sea over the busy port, others face inwards towards the land or walls of graves.

There is one memorial sculpture that catches my eye, a woman in marble with stone clothes so fine it seems they will move in the slightest sea breeze. I watch her and wait for it, but much of the movement here is frozen in time. I pass by names: Balaguer, Fuster, Lull, Miró, Mollet, Puig. Their names reach into blue sky, names I don't know, so many of them with stories buried in this place. Is there a part of Barcelona that rests with them in their graves, a forgotten piece of history that attached itself to their bodies as they walked the streets, as I now do? This city is starting to get inside me now; I find its patterns in the way I move through the streets and metro without thinking, the way I expect conversations with neighbours, the way I avoid walking on the grass. 
It wasn't the first time I'd idled through a space that seemed like it should be more sacred. I used to live opposite the Melbourne Cemetery and would often pass through it as a pleasant short cut. One day a young man approached me with a note in hand and asked me to put it on the gravestone I was visiting, as he had no family in any cemetery to give it to. I had to tell him that I was also passing through, that I had no one to commemorate there.

When I look more closely here in Montjuïc I notice that it's not that time is static, but rather that it moves more slowly. The weeds are left to inch between the cracks while bouquets of flowers slowly decompose without water, their dried petals leaching colour between visits. There is a flurry of movement - brilliantly coloured expressions of new grief - that slowly fades while no one is watching. It's a peaceful place where there is no longer the pressure to rush, where residents no longer fight against time.

Does it matter where I'm buried? I haven't visited my relatives in their Melbourne graveyards, but I wish I could have taken that young man's note and shared it with someone here in Montjuïc who might have understood the pain in his face.

Someday I might have a less idle reason to visit again.

\section{Bibliography}

BRICKELL, K. \& DATTA, A. (eds.) 2011. Translocal Geographies Space, Places, Connections, Farnham and Burlington: Ashgate.

CURTIS, B. 2001. That Place Where: Some thoughts on Memory and the City. In: IAN, B., KERR, J. \& RENDALL, J. (eds.) The Unknown City: Contesting Architecture and Social Space. Cambridge and London: MIT Press.

PILE, S. 2001. The Un(known) city... or an Urban Geography of What Lies Beneath. In: IAN, B., KERR, J. \& RENDALL, J. (eds.) The Unknown City: Contesting Architecture and Social Space. Cambridge and London: MIT Press.

RENDALL, J. 2001. "Bazaar Beauties" or "Pleasuer Is Our Pursuit": A Spatial Story of Exchange. In: IAN, B., KERR, J. \& RENDALL, J. (eds.) The Unknown City: Contesting Architecture and Social Space. Cambridge and London: MIT Press.

Claire Rosslyn Wilson is a poet, nonfiction writer and researcher who is currently a $\mathrm{PhD}$ candidate of creative writing at the University of Canberra. 
Coolabah, No.23, 2018, ISSN 1988-5946, Observatori: Centre d'Estudis Australians / Australian Studies Centre, Universitat de Barcelona

\section{Contributors}

For more info on Adam Aitken go to adamaitken@wordpress.com

Amanda Anastasi's poetry can be found as locally as the walls of Artist Lane in Prahran, Melbourne, and as far as the Massachusetts Review in Boston

Grant Caldwell is a poet and novelist, and a senior lecturer in Creative Writing at the University of Melbourne.

Aidan Coleman is an Adelaide poet, working on a biography of John Forbes.

Dan Disney lives in Seoul, and teaches with Sogang University's English Literature Program.

Joe Dolce is a composer-poet; winner of the 2017 University of Canberra Health Poetry Prize.

Laurie Duggan's Selected Poems 1971-2017 appears from Shearsman early in 2018.

Marisa Fazio writes short form poetry and prose which have been published in journals and anthologies world-wide.

Barry Gillard lives, writes and teaches in Geelong, Victoria.

Jeff Guess: Eleven collections. Web: www.jeffguess.com Visit Jeff Guess on YouTube.

Matt Hetherington sometimes knows when to stop.

Andy Jackson's most recent book is Music Our Bodies Can't Hold (Hunter Publishers 2017), which consists of portrait poems of other people with Marfan Syndrome.

Ross Jackson lives in Perth, Western Australia and his work has appeared on the Web and in many literary journals.

Leanne Jaeger is a Tasmanian poet, artist and musician.

John Jenkins is an incredibly handsome, charismatic liar.

Ray Liversidge has published four full-length collections of poetry and has a new manuscript ready to go if any publisher out there is interested.

Justin Lowe is an internationally published poet and author who currently edits poetry blog Bluepepper in the blue mountains west of Sydney.

Mark Mahemoff — I reside in Sydney but live in my head.

Michaela Mark, M.A. is a 32 year old mother of one, and the proud custodian of a reader's physique. 
Alex McKeown is a poet and translator based in Hobart, Australia.

Julian McLucas - Artist \& gardener living on the land of the dja dja wurrung.

Sometimes Jan Napier's poems fly, sometimes...

Nathanael O'Reilly is an Australian poet residing in Texas; his most recent book is Preparations for Departure (UWAP Poetry, 2017).

Geoff Page is a poet based in Canberra whose most recent collection is Hard Horizons (Pitt Street Poetry)

Gregory Piko is an award-winning haiku and free poet who lives in Yass, New South Wales and blogs at www.gregorypiko.com

Jan Price's poetry, painting and photography have granted her a public life.

Chris Ringrose is a writer from Melbourne, Australia, whose poems have been getting shorter as he has been getting older.

Rob Scott has been writing haiku since 1997.

Lel Sebastian's poems have appeared in a handful of Australian poetry journals, and been broadcast on Radio National.

Claire Rosslyn Wilson is a poet, writer and researcher who is currently a $\mathrm{PhD}$ candidate of creative writing at the University of Canberra. http://clairerosslynwilson.com/

Copyright@2018 Adam Aitken, Amanda Anastasi, Grant Caldwell, Aidan Coleman, Dan Disney, Joe Dolce, Laurie Duggan, Marisa Fazio, Barry Gillard, Jeff Guess, Matt Hetherington, Andy Jackson, Ross Jackson, Leanne Jaeger, John Jenkins, Ray Liversidge, Justin Lowe, Mark Mahemoff, Michaela Mark, Alex McKeown, Julian McLucas, Jan Napier, Nathanael O'Reilly, Geoff Page, Gregory Piko, Jan Price, Chris Ringrose, Rob Scott, Lel Sebastian, Claire Rosslyn Wilson. This text may be archived and redistributed both in electronic form and in hard copy, provided that the author and journal are properly cited and no fee is charged, in accordance with our Creative Commons Licence. 